\title{
Screening of the Dichloromethane: Methanolic Extract of Centella asiatica for Antibacterial Activities against Salmonella typhi, Escherichia coli, Shigella sonnei, Bacillus subtilis, and Staphylococcus aureus
}

\author{
Berick Moturi Sieberi $(\mathbb{D}$, George Isanda Omwenga, Rachael Kitondo Wambua, \\ Judith Chemutai Samoei, and Mathew Piero Ngugi $\mathbb{D}$ \\ Department of Biochemistry, Microbiology and Biotechnology, School of Pure and Applied Sciences, Kenyatta University, \\ 43844-00100 Nairobi, Kenya \\ Correspondence should be addressed to Berick Moturi Sieberi; bericksm@gmail.com
}

Received 22 November 2019; Revised 29 February 2020; Accepted 9 June 2020; Published 1 July 2020

Academic Editor: Amal G. Al-Bakri

Copyright (C) 2020 Berick Moturi Sieberi et al. This is an open access article distributed under the Creative Commons Attribution License, which permits unrestricted use, distribution, and reproduction in any medium, provided the original work is properly cited.

\begin{abstract}
Bacterial infections are responsible for a large number of deaths every year worldwide. On average, $80 \%$ of the African population cannot afford conventional drugs. Moreover, many synthetic antibiotics are associated with side effects and progressive increase in antimicrobial resistance. Currently, there is growing interest in discovering new antibacterial agents from ethnomedicinal plants. About $60 \%$ of the population living in developing countries depends on herbal drugs for healthcare needs. This study involved the screening of Centella asiatica commonly used by herbal medicine practitioners in Kisii County to treat symptoms related to bacterial infections. Standard bioassay methods were applied throughout the study. They included preliminary screening of dichloromethane: methanolic extract of Centella asiatica against human pathogenic bacteria including Salmonella typhi ATCC 19430, Escherichia coli ATCC 25922, Shigella sonnei ATCC 25931, Bacillus subtilis ATCC 21332, and Staphylococcus aureus ATCC 25923 using agar disc diffusion, broth microdilution method, and time-kill kinetics with tetracycline as a positive control. Phytochemical screening was carried out to determine the different classes of compounds in the crude extracts. Data were analyzed using one way ANOVA and means separated by Tukey's test. Dichloromethane: methanolic extract of Centella asiatica was screened against the selected bacterial strains. Time-kill kinetic studies of the extracts showed dose- and time-dependent kinetics of antibacterial properties. Phytochemical screening of the DCM-MeOH extract revealed the presence of alkaloids, flavonoids, phenolics, terpenoids, cardiac glycosides, saponins, steroids, and tannins. The present study indicates that the tested plant can be an important source of antibacterial agents and recommends that the active phytoconstituents be isolated, identified, and screened individually for activities and also subjected further for in vivo and toxicological studies.
\end{abstract}

\section{Introduction}

Infectious diseases are a major cause of morbidity and mortality worldwide [1-3]. The use of antibiotics to control these diseases has led to the emergence of antibiotic-resistant pathogens and, therefore, the need for alternative medicines $[4,5]$, such as medicinal plants [6], which are easily available, affordable, and efficacious with minimal side effects $[7,8]$. The problem of antibiotic resistance is confounded by the emergence of "superbugs" such as Staphylococcus aureus, Mycobacterium tuberculosis, Enterobacter species, Klebsiella pneumoniae, Acinetobacter baumannii, and Pseudomonas aeruginosa that are resistant to multiple classes of antibiotics $[9,10]$.

In addition, many bacterial pathogens form biofilms when they come in contact with a hydrated surface [11]. The biofilms are extracellular matrices that enclose aggregates of bacterial cells on surfaces $[11,12]$ and are a major problem in 
clinical therapeutics since microbial communities adhered to surfaces are physiologically distinct from planktonic cells of the same bacteria [13]. The formation of bacterial biofilms has been shown to increase resistance to antibiotics by up to 1000 -fold [14]. In bacterial culture, a growth medium is required which is a culture media either in a solid, liquid, or semisolid form designed to support the growth of bacteria. A culture media used for general cultivation and maintenance of bacteria contains a carbon source, water, salts, amino acids, and nitrogen [15].

About $80 \%$ of the population living in developing countries uses medicinal plants for their health care needs due to their inability to maintain a steady supply of conventional medicines $[7,16]$. In some cases, herbal drugs are used in combination with conventional drugs if the patient feels that the prescribed medicines are ineffective [17].

The World Health Organization (WHO) emphasizes the need to compliment conventional treatment with herbal medicines [18], and through its sensitization and mobilization programs, African countries have been encouraged to begin serious advancements in herbal medicine use in order to sustain provision of healthcare and ensure continuity of culture [16]. Exploiting plant extracts with known antibacterial activities is significant in managing various infectious diseases [19].

Bacterial resistance to currently used antibiotics necessitates the search for effective therapeutic agents. The use of medicinal plants presents a great potential as a source of antimicrobial compounds against resistant pathogenic microorganisms [20].

Medicinal plants have been used for a long time [21] and have a track record of being effective, safe, and cheap to use [22]. For instance, Glycyrrhiza glabra has been used for the management of respiratory ailments such as coughs, sore throat, and bronchitis [23] and Mahonia aquifolium has been used in skin infection management [24], while Achillea millefolium and Arctostaphylos uva-ursi are used to manage urinary tract infections $[25,26]$.

A large number of people in developing countries depend on medicinal plants as their primary source of medication [27].

Centella asiatica has been utilized traditionally for the treatment of infectious diseases among the Abagusii community in Kenya, with limited scientific documentation of its dichloromethane: methanolic extract antibacterial activities. This study aimed at screening the dichloromethane: methanolic extract of Centella asiatica for antibacterial activities against selected bacterial pathogens.

Centella asiatica is used to treat wounds, mental and neurological disorders, atherosclerosis, microbial infections, and cancer [28]. It is also used in the treatment of inflammations, diarrhea, asthma, tuberculosis, and various skin lesions and ailments such as leprosy, lupus, psoriasis, and keloid. It is reported to possess ulcer-preventive, antioxidant, and antidepressive effects and improves venous insufficiency. An alcoholic extract of the whole plant showed antiprotozoal activity against E. histolytica [28], while a chloroform extract of the whole plant showed activity against Bacillus subtilis, Staphylococcus aureus, Bacillus cereus, Escherichia coli, Salmonella typhi, and Shigella dysenteriae.

Centella asiatica $\mathrm{L}$. is a member of the family Umbeliferae; the photograph of the plant is presented in Figure 1. It is a perennial herbaceous creeper that grows in moist areas and is distributed widely in tropical and subtropical countries [29]. It has a faint aroma with white to pink flowers and 1-3 leaves of sheathing base from each node. The leaves are smooth with parallel lines on the surface and roots at the stem nodes. The fruits are about 2 inches long and spherical shaped with a thick pericarp. Its seeds consist of a pedulous embryo that looks compressed [29-31]. Vernacular names include English- Indian pennywort, Hindi- Gotukolu, and Chinese- Fo-ti-tieng, while in Kenya, it is referred to as Mungutab beliot ne sing'ortot (nandi) and Enyonyo engare (Kisii).

\section{Materials and Methods}

2.1. Plant Sample Collection and Preparation. Whole plant samples of Centella asiatica were sourced from Masaba south sub-County in Kisii County, Kenya, under accepted bioconservation methods with the help of a local herbalist. A fresh sample was botanically authenticated by an acknowledged taxonomist, Mr. Lucas Karimi, from the Pharmacy Department, Kenyatta University, and assigned a voucher specimen number BM/26345/001/2016. A sample voucher was deposited at the Department of Pharmacy research herbarium of Kenyatta University. The plant samples were transported to Kenyatta University, Department of Biochemistry, Microbiology and Biotechnology laboratories, washed with clean water to remove soil, and dried under shade for 14 days. The samples were then milled into a fine powder with an electric mill. The powder was weighed and stored at room temperature in airtight containers, awaiting extraction.

2.2. Extraction. Two hundred grams $(200 \mathrm{~g})$ of the plant sample powder was weighed and soaked in a cold $600 \mathrm{ml}$ mixture of dichloromethane: methanol $(1: 1)$ for $48 \mathrm{~h}$ in a flask to obtain the extract [32]. After extraction, it was decanted and, then, filtered using Whatman No. 1 filter papers, and the filtrate was concentrated under vacuum using a rotary evaporator at $40^{\circ} \mathrm{C}$. The extract obtained was kept in an airtight container and stored at $-20^{\circ} \mathrm{C}$ for later use in an antimicrobial assay.

2.3. Experimental Design. A completely randomized design was applied in this study.

2.4. Tested Microorganisms. Microorganisms used in the experiment were standard reference strains sourced from the Microbiology laboratory, Kenyatta University, namely, Salmonella typhi (ATCC 19430), Escherichia coli (ATCC 25922), Shigella sonnei (ATCC 25931), Bacillus subtilis (ATCC 21332), and Staphylococcus aureus (ATCC 25923). 


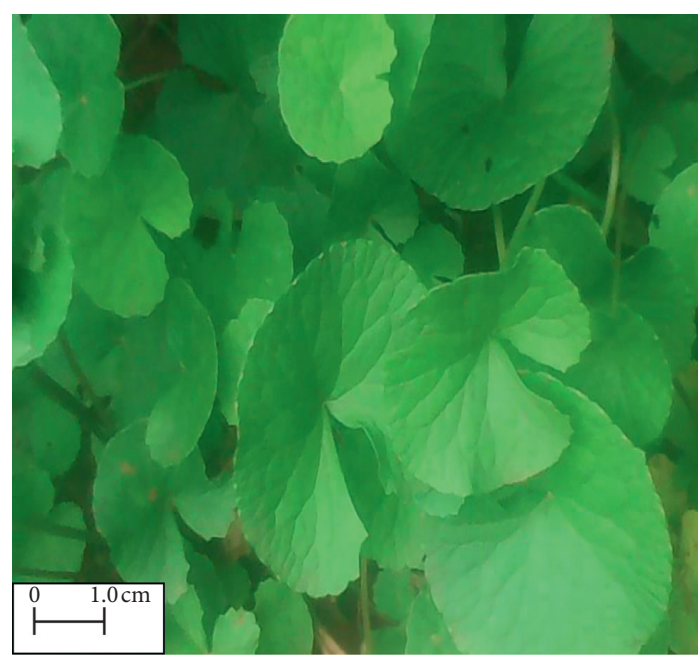

Figure 1: Picture of Centella asiatica L.

2.4.1. Maintenance of Microbial Stock Cultures. The stock cultures of bacterial strains were cultured on Mueller Hinton agar and incubated at $37^{\circ} \mathrm{C}$ for $24 \mathrm{~h}$ to obtain fresh growing colonies [33]. Three to four colonies were transferred using a sterile wire loop into sterile capped glass tubes with $10 \mathrm{ml}$ of sterile Mueller Hinton broth and incubated at $37^{\circ} \mathrm{C}$ for $24 \mathrm{~h}$ to obtain a fresh growing bacterial suspension and maintained at $4^{\circ} \mathrm{C}$.

\subsection{Preparation of Plant Extract Dilutions and Impregnated} Antimicrobial Agent Discs. The plant extract stock solution was reconstituted using $0.2 \%$ DMSO by weighing $1 \mathrm{~g}$ of the extract in a sterile sample bottle and dissolved in $1 \mathrm{ml} 0.2 \%$ DMSO to make a concentration of $1 \mathrm{~g} / \mathrm{ml}$. The stock solution was then diluted serially in a two-fold dilution starting from $500 \mathrm{mg} / \mathrm{ml}$. Paper discs of $6 \mathrm{~mm}$ in diameter were prepared from Whatman No. 1 filter paper using a paper punch and sterilized at $121^{\circ} \mathrm{C}$ for $15 \mathrm{~min}$. Twenty microlitres from each of the different concentrations was used to impregnate the paper discs. The impregnated discs were air dried in a laminar flow hood for $3 \mathrm{~h}$ and immediately used for the sensitivity tests.

\subsection{Antimicrobial Sensitivity Test Using the Disc Diffusion} Method. The assays for antimicrobial activity of the DCM: methanolic extract of $C$. asiatica were performed by the disc diffusion method [34]. Bacteria from the stock cultures were cultured overnight at $37^{\circ} \mathrm{C}$ in MHA and used as the inoculum. Bacterial cultures were adjusted to $0.5 \mathrm{McF}$ arland's standard to achieve a concentration of $1.5 \times 10^{8} \mathrm{CFU} / \mathrm{ml}$ in physiological saline and then used to lawn Mueller-Hinton agar plates evenly using sterile cotton swabs. The inoculated plates were air-dried in the laminar airflow hood for $15 \mathrm{~min}$ and, then, used for the sensitivity test. The discs, impregnated with a series of plant extract dilutions, were placed on the Mueller-Hinton agar surface with each test plate comprising eight discs equidistant from each other. A standard commercial antibiotic disc (Tetracycline $30 \mu \mathrm{g}$ ) was used as a positive control, while a disc impregnated with $0.2 \%$ DMSO was used as the negative control. The plates were incubated at $37^{\circ} \mathrm{C}$ for $24 \mathrm{~h}$ after which zones of inhibition around the discs were observed and measured. The tests were performed in triplicates.

2.7. Determination of Minimum Inhibitory Concentrations (MICs). The broth microdilution method was used to determine minimum inhibitory concentrations (MICs) of the plant extract against the test bacterial cultures using 96-well microtiter plates [35]. Starting from the highest concentration of each extract, two-fold serial dilutions were prepared in sterile MHB in sterile test tubes, resulting in a concentration range from $500 \mathrm{mg} / \mathrm{ml}$ to $7.8125 \mathrm{mg} / \mathrm{ml}$, the wells were clearly labeled with the respective extract concentration, and $50 \mu \mathrm{l}$ of each extract dilution was added into the respective well for each bacterial isolate to be tested. Each well containing the extract dilution and the growth control well was inoculated with $50 \mu \mathrm{l}$ of the bacterial suspension to achieve a final inoculum of $5 \times 10^{5} \mathrm{CFU} / \mathrm{ml}$, and the plate was incubated at $37^{\circ} \mathrm{C}$ for $24 \mathrm{~h}$.

Ten microlitre $(10 \mu \mathrm{l})$ samples from the growth control well were removed immediately after inoculation and mixed with $990 \mu \mathrm{l}$ of sterile MHB in a sterile microcentrifuge tube. This suspension was further diluted by taking $100 \mu \mathrm{l}$ and adding to $900 \mu \mathrm{l}$ sterile MHB. A hundred microlitres $(100 \mu \mathrm{l})$ from each of the dilutions was plated on nutrient agar and incubated at $37^{\circ} \mathrm{C}$ for $24 \mathrm{~h}$ together with the microtiter plate. Colonies were counted after $24 \mathrm{~h}$ of incubation to confirm the $\mathrm{CFU} / \mathrm{ml}$ present in the innocula.

The MIC was recorded as the lowest concentration of the extract that inhibited visible growth of the test bacteria as observed by an unaided eye. Each experiment was performed in triplicate.

\subsection{Determination of Minimum Bactericidal Concentrations} $(M B C s)$. Samples of $10 \mu \mathrm{l}$ from each well with a concentration at and above the MIC of the antimicrobial agent being tested [32] were taken, and the inoculum was spread over the MHA plate with a sterile cotton swab [36]. The plates were incubated at $37^{\circ} \mathrm{C}$ for $24 \mathrm{~h}$. After incubation, visible colonies were counted on each subculture plate, as well as the initial inoculum plates. The MBC was recorded as the lowest concentration of the plant extract in which there was a reduction of the initial inoculum by $99.9 \%$ [37].

2.9. Determination of Time-Kill Kinetics. Time-kill kinetics was carried out to indicate the rate and extent of bacterial killing by the antibacterial agent [38], based on the MIC and $\mathrm{MBC}$ reactions [34].

2.9.1. Preparation of the Inoculum. Twenty-four hour cultures of the test microorganisms on MHA were suspended in MHB to obtain bacterial suspension of $1 \times 10^{6} \mathrm{CFU} / \mathrm{ml}$. One microlitre $(1 \mathrm{ml})$ of the bacterial suspension was added to $9 \mathrm{ml}$ of MHB containing the extract. 
2.9.2. Plant Extract Preparation. The C. asiatica DCM: methanolic extract was prepared in $\mathrm{MHB}$ to a final concentration corresponding to $1 \times \mathrm{MBC}, 2 \times \mathrm{MBC}, 3 \times \mathrm{MBC}$, and $4 \times \mathrm{MBC}$. From each concentration, $9 \mathrm{ml}$ was mixed with $1 \mathrm{ml}$ of the inoculum prepared as mentioned above and incubated at $37^{\circ} \mathrm{C}$. A growth control with only the bacterial cultures in $\mathrm{MHB}$ and a culture with tetracycline drug were used as a negative and positive control, respectively. Five hundred microlitre samples were taken from each test tube at times of $0,0.5,1,2,3,4,6,8,12$, and $24 \mathrm{~h}$ after incubation and diluted tenfold in physiological saline. A hundred microlitres $(100 \mu \mathrm{l})$ of each dilution was plated on MHA and plates incubated at $37^{\circ} \mathrm{C}$ for $24 \mathrm{~h}$. Growing colonies were counted after $24 \mathrm{~h}$ of incubation with only plates containing 30-300 colonies of each dilution counted. Growth curves were plotted to show the $\log _{10}$ of colony forming units (CFU) against time [39, 40].

2.10. Qualitative Phytochemical Screening. Qualitative phytochemical screening was performed on the plant extract to determine the presence or absence of bioactive compounds [41].

2.11. Statistical Analysis. Experimental data on zones of inhibition readings, MIC, MBC, and time-kill kinetics were recorded and tabulated on a broad spread sheet using MS excel program. Statistical analysis of the data was performed using Minitab statistical software version 17.0.

In order to test for parametric assumptions, results were expressed as mean \pm standard error of the mean (SEM). One-way ANOVA and Tukey's post-hoc test were used for separation and comparison of means to obtain the specific significance difference. The values of $p \leq 0.05$ were considered to be significant. The time-kill kinetics plot of $\log _{10} \mathrm{CFU}$ against time was drawn to determine the time required to kill all the bacteria.

\section{Results}

3.1. Antibacterial Sensitivity of the Extract. In this study, the dichloromethane: methanolic extracts of C. asiatica demonstrated antibacterial activities against E. coli, S. typhi, S. aureus, B. subtilis, and S. sonnei. Tetracycline $(30 \mu \mathrm{g})$ was used as a positive control, and 0.2\% DMSO was used as a negative control. The antibacterial effects of the reference drug (tetracycline) were significantly higher against the five bacterial species compared with the $C$. asiatica extract at all concentrations tested $(p<0.05$; Table 1$)$. The inhibitory activities of the $C$. asiatica extract concentration of $500 \mathrm{mg} /$ $\mathrm{ml}$ were significantly higher against the five bacterial species tested compared to the other extract concentrations tested $(p<0.05$; Table 1$)$. The same trend was observed when $C$. asiatica extracts were tested at $250 \mathrm{mg} / \mathrm{ml}$ and $125 \mathrm{mg} / \mathrm{ml}$. At the lower $C$. asiatica extract concentrations, there were no significant inhibitory activities that were recorded against the test bacterial species; thus, the activity was dose-dependent $(p<0.05$; Table 1$)$.
3.2. Minimum Inhibitory Concentrations (MICs) and Minimum Bactericidal Concentrations (MBCs). The MIC values obtained for the DCM : $\mathrm{MeOH}$ extract of $C$. asiatica against Salmonella typhi and Escherichia coli were significantly higher compared to those against $S$. aureus $(p<0.05 ; \mathrm{Ta}-$ ble 2). The MIC values of the extract against $S$. sonnei, $B$. subtilis, and $S$. aureus were not significantly different from each other $(p<0.05$; Table 2). The MBC values obtained for the extract against Salmonella typhi and E. coli were not significantly different from each other, but were significantly higher than the MBC obtained for Staphylococcus aureus, Shigella sonnei, and B. subtilis $(p<0.05$; Table 2$)$.

3.3. Time Kill Kinetics. The time-kill kinetics of the extract concentrations of $C$. asiatica showed similar trends in all the bacterial species tested, with the $\log _{10} \mathrm{cfu}$ declining with time (Figures 2-6). In all the bacterial species, there were slow $\log _{10} \mathrm{CFU}$ decline from 0 to $12 \mathrm{~h}$ followed by a drastic reduction in $\log _{10}$ CFU at the $24^{\text {th }}$ hour.

3.4. Phytochemical Screening. Qualitative phytochemical screening of the dichloromethane: methanolic extract of $C$. asiatica revealed the presence of alkaloids, flavonoids, phenolics, tepenoids, cardiac glycosides, saponins, and tannins, but steroids were absent (Table 3).

\section{Discussion}

The inhibition of S. aureus, E. coli, S. typhi, B. subtilis, and Shigella sonnei by the DCM: $\mathrm{MeOH}$ extract of $C$. asiatica shows that this extract has antibacterial compounds. This extract was more potent on Gram-negative than on Grampositive strains, thus acting as a broad spectrum. These findings are consistent with other reported research works, and this could be attributed to the presence of a lipophilic outer membrane consisting of lipopolysaccharide molecules with an affinity for lipophilic molecules [42]. The phytochemicals present in this extract have been reported to inhibit the growth of both Gram-negative bacteria such as E.coli, V. cholera, P. aeruginosa, S. senftenberg, and Shigella dysenteriae and Gram-positive such as S. aureus, S. mutans, S. pneumoniae, B. anthracis, and B. subtilis [8, 43-47]. Thus, they are acting as a broad spectrum similar to tetracycline activities.

The results obtained showed that the extract contained different phytochemicals that included alkaloids, cardiac glycosides, saponins, tannins, flavonoids, terpenoids, and phenols.

Phenolic compounds have been reported to have an antibacterial activity against Staphylococcus aureus [8], while flavonoids such as quercetin have been reported to completely inhibit the growth of $S$. aureus [46], and catechins have been reported to have in vitro activity against $V$. cholerae, Streptococcus mutans, and Shigella. Quercetin inhibits $E$. coli as naringenin and sophoraflavanone $G$ have been reported to have intensive activity against MRSA and streptococci [45]. Terpenes in cinnamon oil have been observed to inhibit $P$. aeruginosa [47]. Tannin extracts have 
TABLE 1: Zones of inhibition produced by the C. asiatica extract against bacteria strains in mm.

\begin{tabular}{|c|c|c|c|c|c|c|}
\hline \multirow{2}{*}{ Group } & \multicolumn{6}{|c|}{ Zones of inhibition (mm) } \\
\hline & Treatment & Staphylococcus aureus & Escherichia coli & Salmonella typhi & Bacillus subtlis & Shigella sonnei \\
\hline Negative control & DMSO & $6.00 \pm 0.00^{\mathrm{d}}$ & $6.00 \pm 0.00^{\mathrm{f}}$ & $6.00 \pm 0.00^{\mathrm{e}}$ & $6.00 \pm 0.00^{\mathrm{d}}$ & $6.00 \pm 0.00^{\mathrm{d}}$ \\
\hline Positive control & Tetracycline & $29.33 \pm 0.67^{\mathrm{a}}$ & $26.67 \pm 0.33^{\mathrm{a}}$ & $27.67 \pm 0.33^{\mathrm{a}}$ & $22.67 \pm 0.33^{\mathrm{a}}$ & $25.33 \pm 0.33^{\mathrm{a}}$ \\
\hline \multirow{6}{*}{$\begin{array}{l}\text { C. asiatica DCM: } \\
\mathrm{MeOH} \text { extract }\end{array}$} & $15.625 \mathrm{mg} / \mathrm{ml}$ & $6.00 \pm 0.00^{\mathrm{d}}$ & $6.00 \pm 0.00^{\mathrm{f}}$ & $6.00 \pm 0.00^{\mathrm{e}}$ & $6.00 \pm 0.00^{\mathrm{d}}$ & $6.00 \pm 0.00^{\mathrm{d}}$ \\
\hline & $31.25 \mathrm{mg} / \mathrm{ml}$ & $6.00 \pm 0.00^{\mathrm{d}}$ & $6.00 \pm 0.00^{f}$ & $6.00 \pm 0.00^{\mathrm{e}}$ & $6.00 \pm 0.00^{\mathrm{d}}$ & $6.00 \pm 0.00^{\mathrm{d}}$ \\
\hline & $62.5 \mathrm{mg} / \mathrm{ml}$ & $6.00 \pm 0.00^{\mathrm{d}}$ & $7.33 \pm 0.33^{\mathrm{e}}$ & $6.00 \pm 0.00^{\mathrm{e}}$ & $6.00 \pm 0.00^{\mathrm{d}}$ & $6.00 \pm 0.00^{\mathrm{d}}$ \\
\hline & $125 \mathrm{mg} / \mathrm{ml}$ & $6.00 \pm 0.00^{\mathrm{d}}$ & $8.67 \pm 0.33^{d}$ & $8.00 \pm 0.33^{\mathrm{d}}$ & $6.00 \pm 0.00^{\mathrm{d}}$ & $7.33 \pm 0.33^{\mathrm{d}}$ \\
\hline & $250 \mathrm{mg} / \mathrm{ml}$ & $9.67 \pm 0.33^{c}$ & $13.67 \pm 0.33^{c}$ & $10.67 \pm 0.33^{c}$ & $7.67 \pm 0.33^{c}$ & $9.00 \pm 0.58^{c}$ \\
\hline & $500 \mathrm{mg} / \mathrm{ml}$ & $12.00 \pm 0.58^{\mathrm{b}}$ & $16.33 \pm 0.33^{\mathrm{b}}$ & $13.00 \pm 0.58^{\mathrm{b}}$ & $9.67 \pm 0.33^{\mathrm{b}}$ & $15.67 \pm 0.33^{b}$ \\
\hline
\end{tabular}

Values are expressed as mean \pm standard error of the mean (SEM) for triplicate reading. Values with the same superscript letter in the columns are not significantly different by one-way ANOVA followed by Tukey's post-hoc test.

TABLE 2: Minimum inhibitory concentrations (MICs) and minimum bactericidal concentrations (MBCs) for bacteria test cultures in $\mathrm{mg} / \mathrm{ml}$.

\begin{tabular}{lcccc}
\hline & \multicolumn{4}{c}{ Concentration } \\
& C. asiatica $(\mathrm{mg} / \mathrm{ml})$ & Tetracycline $(\mu \mathrm{g} / \mathrm{ml})$ \\
& MIC & MBC & MIC & MBC \\
\hline S. typhi & $62.50 \pm 0.00^{\mathrm{a}}$ & $125.00 \pm 0.00^{\mathrm{a}}$ & $1.96 \pm 0.22^{\mathrm{b}}$ & $3.91 \pm 0.00^{\mathrm{b}}$ \\
S. sonnei & $52.1 \pm 10.40^{\mathrm{ab}}$ & $62.50 \pm 0.00^{\mathrm{b}}$ & $4 \pm 0.00^{\mathrm{a}}$ & $32 \pm 0.00^{\mathrm{a}}$ \\
B.subtilis & $52.1 \pm 10.40^{\mathrm{ab}}$ & $62.50 \pm 0.00^{\mathrm{b}}$ & $1.96 \pm 0.22^{\mathrm{b}}$ & $15.63 \pm 0.1^{\mathrm{a}}$ \\
E.coli & $62.50 \pm 0.00^{\mathrm{a}}$ & $125.00 \pm 0.00^{\mathrm{a}}$ & $0.98 \pm 1.0^{\mathrm{c}}$ & $3.91 \pm 0.00^{\mathrm{b}}$ \\
S.aureus & $26.04 \pm 5.21^{\mathrm{b}}$ & $52.10 \pm 10.4^{\mathrm{b}}$ & $0.25 \pm 0.00^{\mathrm{c}}$ & $1.96 \pm 0.00^{\mathrm{c}}$ \\
\hline
\end{tabular}

Values are expressed as mean \pm standard error of the mean (SEM) for triplicate reading. Values with the same superscript letter in the columns are not significantly different by one-way ANOVA followed by Tukey's posthoc test.

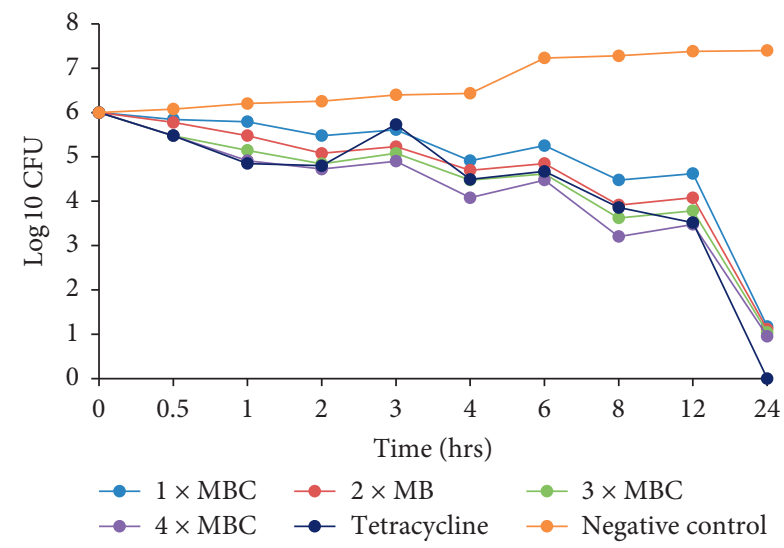

FIgURE 2: Time-kill kinetics activities of the dichloromethane: methanolic extract of C. asiatica against E. coli.

been reported to inhibit $S$. aureus, B. subtilis, and Shigella dysenteriae and, therefore, act as a broad spectrum antimicrobial, while 2, 3, 4-tetrakis- $\alpha$-D-glucosylpyranose is reported to inhibit $S$. aureus [44].

Alkaloids such as ramiflovines A and B extracted from Aspidosperma ramiflovum were found to be significantly active against $S$. aureus and E. faecalis [47], while cryptolepine and quindoline from Sida acuta are reported to be active against $S$. aureus, $S$. dysenteriae, B. cereus. E. faecalis, and E. coli, thus acting as a broad spectrum [48], and

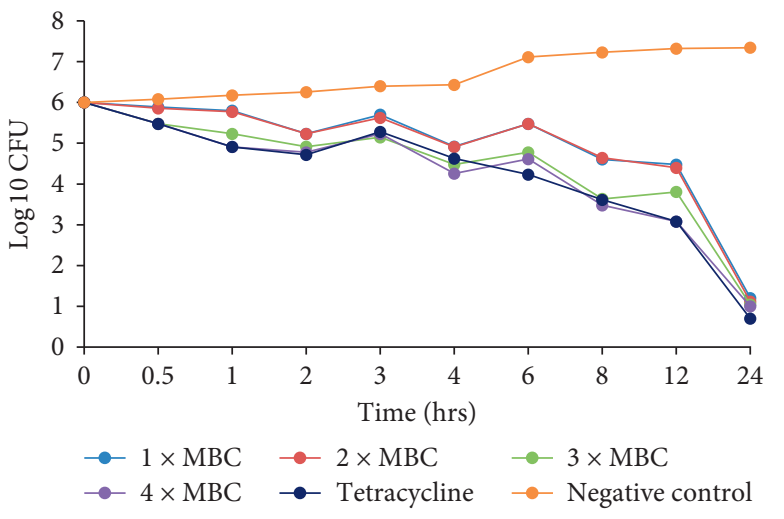

FIgure 3: Time-kill kinetics activities of the dichloromethane: methanolic extract of C. asiatica against S. typhi.

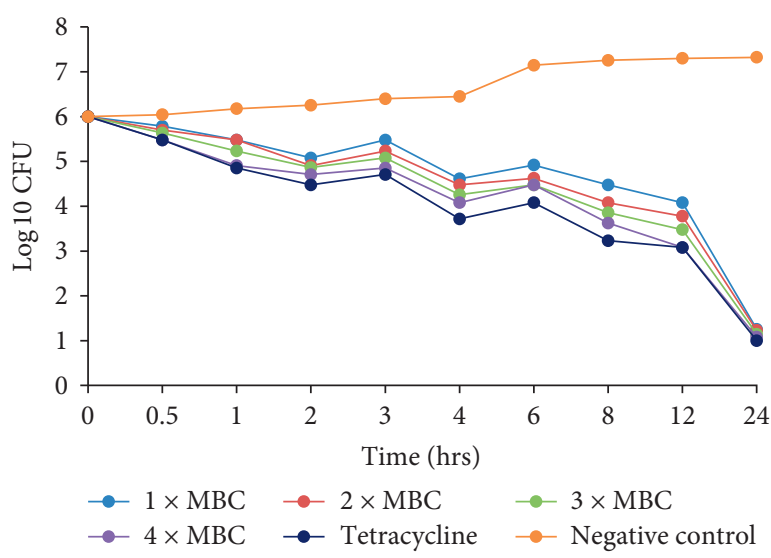

FIgURE 4: Time-kill kinetics activities of the dichloromethane: methanolic extract of $C$. asiatica against Shigella sonnei.

Saponin from Sorghum bicolor L. Moenh was reported to be active against $S$. aureus [49].

Where similar MIC and MBC values against test bacteria were obtained, MIC indicated a bactericidal activity, while those having MBC greater than MIC, the MIC of the extract, in this case, indicated bacteriostatic activity. From all the tests, the values of MBCs obtained were not more than 4 times higher than those of MICs on the corresponding test bacteria indicating that the extracts tested had an antimicrobial activity [42]. 


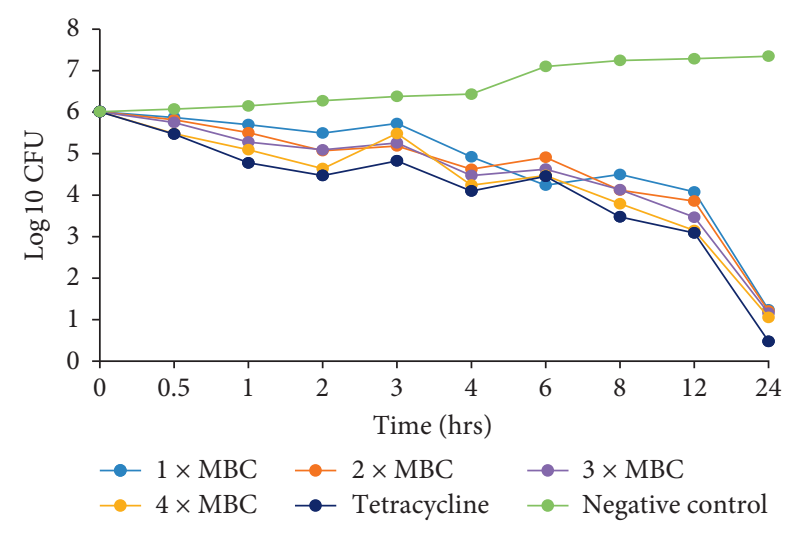

FIGURE 5: Time-kill kinetics activities of the dichloromethane: methanolic extract of $C$. asiatica against $S$. aureus.

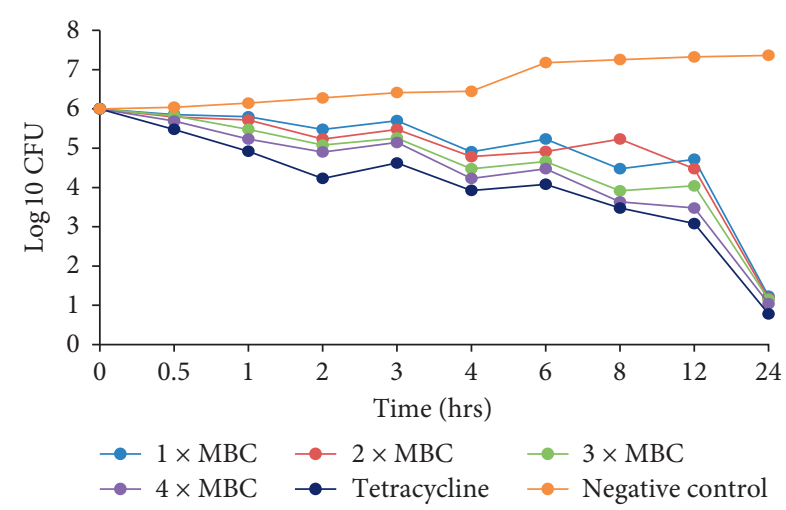

Figure 6: Time-kill kinetics activities of the dichloromethane: methanolic extract of $C$. asiatica against $B$. subtilis.

TABle 3: Phytochemical composition of the dichloromethane: methanolic extract of $C$. asiatica.

\begin{tabular}{lc}
\hline Phytochemical & Centella asiatica \\
\hline Alkaloids & + \\
Flavonoids & + \\
Steroids & - \\
Saponins & + \\
Cardiac glycosides & + \\
Phenolics & + \\
Terpenoids & + \\
Tannins & + \\
\hline
\end{tabular}

Present phytochemicals are denoted by the $(+)$ sign, while the absent phytochemicals are denoted by the (-) sign.

Time-kill kinetics studies of the dichloromethane: methanolic extract of $C$. asiatica at varying concentrations on the test bacteria showed a slow dose- and time-dependent kinetics of killing for both Gram-negative and Gram-positive bacteria. Dose-dependent kinetics occur when the antibacterial agent is at a high concentration at the target site for it to kill the bacteria, while time-dependent kinetics is observed when the concentration of the antibacterial agent is more than the MIC for the test bacteria [50].

The existence of viable bacteria colonies after $24 \mathrm{~h}$ of incubation with the antibacterial agent present could be due to the occurrence of mutant forms which resist and grow in the presence of extract concentrations and change to vegetative forms when antibacterial agents are withdrawn. Mutant bacterial cells devoid of cell wall can be produced by both Gram-negative and Gram-positive bacteria [14]. This could also be due to resistance as a result of biofilm formation, since microbial populations adhered to surfaces are physiologically different from planktonic cells of the same bacteria [13].

\section{Conclusions and Recommendations}

The dichloromethane: methanolic extract of $C$. asiatica showed antimicrobial activities. These findings imply that $C$. asiatica may be a potential candidate to obtain an antimicrobial agent in the management of infectious diseases. This study, therefore, confirms the antibacterial activities of $C$. asiatica and supports its use against bacterial infections in the Gusii community in Kenya and other parts of the world.

Based on the abovementioned conclusion, the following recommendations are forwarded:

(i) The plant part should be extracted with other solvent types to get enough of bioactive molecules

(ii) The different fractions of the plant extract to be evaluated for antibacterial activities

\section{Appendix}

\section{Procedures for the Preparation of Standards}

Procedures to Prepare 0.5 McFarland Standard Solutions. Original McFarland standards were made by mixing specified amounts of barium chloride and sulfuric acid together. Mixing the two compounds forms a barium sulfate precipitate, which causes turbidity in the solution. A 0.5 McFarland standard is prepared by mixing $0.05 \mathrm{ml}$ of $1.175 \%$ barium chloride dihydrate $\left(\mathrm{BaCl}_{2} \bullet 2 \mathrm{H}_{2} \mathrm{O}\right)$ with $9.95 \mathrm{ml}$ of $1 \%$ sulfuric acid $\left(\mathrm{H}_{2} \mathrm{SO}_{4}\right)$. The standard can be compared visually to a suspension of bacteria in sterile saline or nutrient broth. If the bacterial suspension is too turbid, it can be diluted with more diluents. If the suspension is not turbid enough, more bacteria can be added.

\section{Data Availability}

The data used to support the findings of this study are available from the corresponding author upon request.

\section{Conflicts of Interest}

The authors declare that they have no conflicts of interest.

\section{Authors' Contributions}

It is out of the invaluable guidance and mentorship from George Isanda Omwenga and Mathew Piero Ngugi and the inspirational support from Rachael Kitondo Wambua and Judith Chemutai Samoei that this study was a success. 


\section{Acknowledgments}

The authors are grateful for the technical support provided by Catherine Muthoni and Joseph Maingi, both in the Microbiology laboratory, Kenyatta University. The authors' heartfelt thanks also go to Kenyatta University for resource support.

\section{References}

[1] H. C. Schønheyder and M. Paul, "Placing the burden of bacteraemia in perspective," Clinical Microbiology and Infection, vol. 19, no. 6, pp. 489-491, 2013.

[2] F. A. Waldvogel, "Infectious diseases in the 21st century: old challenges and new opportunities," International Journal of Infectious Diseases, vol. 8, no. 1, pp. 5-12, 2004.

[3] World Health Organization, The World Health Report 2002: Reducing Risks, Promoting Healthy Life, World Health Organization, Geneva, Switzerland, 2002.

[4] S. Chanda and K. Rakholiya, "Combination therapy: synergism between natural plant extracts and antibiotics against infectious diseases," Formatex Research Center, pp. 520-529, Microbiology Book Series, Badajoz, Spain, 2011.

[5] S. Sabahat and T. Perween, "Antibacterial activities of Mentha piperita, Pisum sativum and Momordica charantia," Pakistan Journal of Botany, vol. 37, no. 4, p. 997, 2005.

[6] I. Ahmad and A. Z. Beg, "Antimicrobial and phytochemical studies on 45 Indian medicinal plants against multi-drug resistant human pathogens," Journal of Ethnopharmacology, vol. 74, no. 2, pp. 113-123, 2001.

[7] L. Cathrine and N. P. Nagarajan, "Preliminary phytochemical analysis and antibacterial activity of leaf extracts of Vitex leucoxylon LF," International Journal of Current Pharmaceutical Research, vol. 3, no. 3, pp. 71-73, 2011.

[8] M. Saxena, J. Saxena, R. Nema, D. Singh, and A. Gupta, "Phytochemistry of medicinal plants," Journal of Pharmacognosy and Phytochemistry, vol. 1, no. 6, pp. 47-53, 2013.

[9] R. Dabur, A. Gupta, T. K. Mandal et al., "Antimicrobial activity of some Indian medicinal plants," African Journal of Traditional, Complementary and Alternative Medicines, vol. 4, no. 3, pp. 313-318, 2007.

[10] L. C. Ngeny, E. Magiri, C. Mutai, N. Mwikwabe, and C. Bii, "Antimicrobial properties and toxicity of Hagenia abyssinica (bruce) JF gmel, Fuerstia africana TCE fries, Asparagus racemosus (willd.) and Ekebergia capensis sparrm," African Journal of Pharmacology and Therapeutics, vol. 2, no. 3, pp. 76-82, 2013.

[11] W. Costerton, R. Veeh, M. Shirtliff, M. Pasmore, C. Post, and G. Ehrlich, "The application of biofilm science to the study and control of chronic bacterial infections," Journal of Clinical Investigation, vol. 112, no. 10, pp. 1466-1477, 2003.

[12] I. Liaqat, I. A. Saiyed, and J. Nusrat, "Biofilm formation and sporulation in Bacillus subtilis," International Journal of Microbiology Research and Reviews, vol. 1, pp. 061-067, 2013.

[13] P. S. Stewart and J. W. Costerton, "Antibiotic resistance of bacteria in biofilms," International Journal of Medical Microbiology, vol. 292, pp. 107-113, 2001.

[14] S.-C. Park, Y. Park, and K.-S. Hahm, "The role of antimicrobial peptides in preventing multidrug-resistant bacterial infections and biofilm formation," International Journal of Molecular Sciences, vol. 12, no. 9, pp. 5971-5992, 2011.

[15] S. K. Bhattacharya and D. Sur, "An evaluation of current shigellosis treatment," Expert Opinion on Pharmacotherapy, vol. 4, no. 8, pp. 1315-1320, 2003.
[16] M. W. Iwu, A. R. Duncan, and C. O. Okunji, New Antimicrobials of Plant Origin. Perspectives on New Crops and New Uses, pp. 457-462, ASHS Press, Alexandria, VA, USA, 1999.

[17] B. Mahesh and S. Satish, "Antimicrobial activity of some important medicinal plant against plant and human pathogens," World Journal of Agricultural Sciences, vol. 4, no. 1, pp. 839-843, 2008.

[18] A. Safary, H. Motamedi, S. Maleki, and S. M. Seyyednejad, “A preliminary study on the antibacterial activity of Quercus brantii against bacterial pathogens, particularly enteric pathogens," International Journal of Botany, vol. 5, no. 2, pp. 176-180, 2009.

[19] M. M. Nitalikar, K. C. Munde, B. V. Dhore, and S. N. Shikalgar, "Studies of antibacterial activities of Glycyrrhiza glabra root extract," International Journal PharmTech, Research, vol. 2, no. 1, pp. 899-901, 2010.

[20] L. Rackova, M. Oblozinsky, D. Kostalova, V. Kettmann, and L. Bezakova, "Free radical scavenging activity and lipoxygenase inhibition of Mahonia aquifolium extract and isoquinoline alkaloids," Journal of Inflammation, vol. 4, no. 1, p. 15, 2007.

[21] G. Schindler, U. Patzak, B. Brinkhaus et al., "Urinary excretion and metabolism of arbutin after oral administration of Arctostaphylos uvae ursi extract as film-coated tablets and aqueous solution in healthy humans," The Journal of Clinical Pharmacology, vol. 42, no. 8, pp. 920-927, 2002.

[22] S. Yakhkeshi, S. Rahimi, and H. R. Hemati Matin, "Effects of yarrow (Achillea millefolium L.), antibiotic and probiotic on performance, immune response, serum lipids and microbial population of broilers," Journal of Agricultural Science and Technology, vol. 14, no. 4, pp. 799-810, 2012.

[23] A. A. Elujoba, O. M. Odeleye, and C. M. Ogunyemi, "Reviewtraditional medicine development for medical and dental primary health care delivery system in Africa," African Journal of Traditional Complimentary and Alternative Medicine, vol. 2, no. 1, pp. 46-61, 2004.

[24] W. Kipkore, B. Wanjohi, H. Rono, and G. Kigen, "A study of the medicinal plants used by the Marakwet community in Kenya," Journal of Ethnobiology and Ethnomedicine, vol. 10, no. 1, p. 24, 2014.

[25] A. R. O. Nyunja, J. C. Onyango, and B. Erwin, “The Kakamega forest medicinal plant resources and their utilization by the adjacent Luhya community," International Journal of Tropical Medicine, vol. 4, no. 3, pp. 82-90, 2009.

[26] M. K. Kaveri, C. V. B. Kadarnath, and C. S. Patil, "Antimicrobial activity of Aloe vera leaf extract," International Journal of Applied Biology and Pharmaceutical Technology, vol. 4, no. 4, pp. 286-290, 2013.

[27] C. K. Kitonde, D. S. Fidahusein, C. W. Lukhoba, and M. M. Jumba, "Antimicrobial activity and phytochemical study of Vernonia glabra (steetz) oliv. \& hiern in Kenya," African Journal of Traditional, Complementary and Alternative Medicines, vol. 10, no. 1, pp. 149-157, 2012.

[28] E. O. Omwenga, P. O. Okemo, P. K. Mbugua, and C. K. P. Ogol, "Ethnobotanical survey and antimicrobial evaluation of medicinal plants used by the Samburu community (Kenya) for treatment of diarrhorea," Pharmacognosy Magazine, vol. 5, no. 18, p. 165, 2009.

[29] S. Singh, A. Gautam, A. Sharma, and A. Batra, "Centella asiatica (L.): a plant with immense medicinal potential but threatened," International Journal of Pharmaceutical Sciences Review and Research, vol. 4, no. 2, pp. 33-48, 2010.

[30] A. Kirby-Bauer, "Antimicrobial sensitivity testing by agar diffusion method," Journal Clinical Pathology, vol. 45, no. 66, pp. 493-496, 1966. 
[31] D. Bhavna and K. Jyoti, "Centella asiatica: the elixir of life," International Journal of Research in Ayurvedha and Pharmacy, vol. 2, no. 2, pp. 431-438, 2011.

[32] B. K. Dash, H. M. Faruquee, S. K. Biswas, M. K. Alam, S. M. Sisir, and U. K. Prodhan, "Antibacterial and antifungal activities of several extracts of Centella asiatica L. against some human pathogenic microbes," Life Sciences and Medicine Research, vol. 1, pp. 1-5, 2011.

[33] L. Natta, K. Orapin, N. Krittika, and B. Pantip, "Essential oil from five Zingiberaceae for anti food-borne bacteria," International Food Research Journal, vol. 15, no. 3, pp. 1-10, 2008.

[34] NCCLS, Methods for Dilution Antimicrobial Susceptibility Tests for Bacteria that Grow Aerobically. Approved Standard M7-A5, NCCLS, Wayne, PA, USA, 2000.

[35] C. J. Shanholtzer, L. R. Peterson, M. L. Mohn, J. A. Moody, and D. N. Gerding, "MBCs for Staphylococcus aureus as determined by macrodilution and microdilution techniques," Antimicrobial Agents and Chemotherapy, vol. 26, no. 2, pp. 214-219, 1984.

[36] J. H. Jorgensen and J. D. Turnidge, "Susceptibility test methods: dilution and disk diffusion methods," in Manual of Clinical Microbiology, pp. 1253-1273, American Society for Microbiology (ASM), Washington, D.C., USA, 11th edition, 2015.

[37] G. G. Zhanel, J. A. Karlowsky, D. J. Hoban, and R. J. Davidson, "Antimicrobial activity of subinhibitory concentrations of aminoglycosides against Pseudomonas aeruginosa as determined by the killing-curve method and the postantibiotic effect," Chemotherapy, vol. 37, no. 2, pp. 114-121, 1991.

[38] W. Fabry, P. O. Okemo, and R. Ansorg, "Antibacterial activity of east African medicinal plants," Journal of Ethnopharmacology, vol. 60, no. 1, pp. 79-84, 1998.

[39] D. S. Burgess and R. W. Hastings, "Activity of piperacillin/ tazobactam in combination with amikacin, ciprofloxacin, and trovafloxacin against Pseudomonas aeruginosa by time-kill," Diagnostic Microbiology and Infectious Disease, vol. 38, no. 1, pp. 37-41, 2000.

[40] A. J. Harborne, Phytochemical Methods a Guide to Modern Techniques of Plant Analysis, Springer Science \& Business Media, Berlin, Germany, 1998.

[41] C.-G. Kang, D.-S. Hah, C.-H. Kim, Y.-H. Kim, E.-K. Kim, and J.-S. Kim, "Evaluation of antimicrobial activity of the methanol extracts from 8 traditional medicinal plants," Toxicological Research, vol. 27, no. 1, pp. 31-36, 2011.

[42] P. K. Ashok and K. Upadhyaya, "Tannins are astringent," Journal of Pharmacognosy and Phytochemistry, vol. 1, no. 3, pp. 2-6, 2012.

[43] K.-T. Chung, T. Y. Wong, C.-I. Wei, Y.-W. Huang, and Y. Lin, "Tannins and human health: a review," Critical Reviews in Food Science and Nutrition, vol. 38, no. 6, pp. 421-464, 1998.

[44] S. Kumar and A. K. Pandey, "Chemistry and biological activities of flavonoids: an overview," The Scientific World Journal, vol. 2013, Article ID 162750, 16 pages, 2013.

[45] A. R. Tapas, D. M. Sakarkar, and R. B. Kakde, "Flavonoids as nutraceuticals: a review," Tropical Journal of Pharmaceutical Research, vol. 7, no. 3, pp. 1089-1099, 2008.

[46] S. Zwenger, "Plant terpenoids: applications and future potentials," Biotechnology and Molecular Biology Reviews, vol. 3, no. 1, pp. 1-7, 2008.

[47] J. C. A. Tanaka, C. C. d. Silva, A. J. B. d. Oliveira, C. V. Nakamura, and B. P. Dias Filho, "Antibacterial activity of indole alkaloids from Aspidosperma ramiflorum," Brazilian Journal of Medical and Biological Research, vol. 39, no. 3, pp. 387-391, 2006.
[48] M. A. Oyekunle, O. O. Aiyelaagbe, and M. A. Fafunso, "Evaluation of the antimicrobial activity of saponins extract of Sorghum bicolor L. Moench," African Journal of Biotechnology, vol. 5, no. 23, pp. 31-39, 2006.

[49] A. Anantharaman, M. S. Rizvi, and D. Sahal, "Synergy with rifampin and kanamycin enhances potency, kill kinetics, and selectivity of de novo-designed antimicrobial peptides," Antimicrobial Agents and Chemotherapy, vol. 54, no. 5, pp. 1693-1699, 2010.

[50] M. Leaver, P. Domínguez-Cuevas, J. M. Coxhead, R. A. Daniel, and J. Errington, "Life without a wall or division machine in Bacillus subtilis," Nature, vol. 457, no. 7231, pp. 849-853, 2009. 